\title{
THE EFFECT OF GREEN SUPPLY CHAIN MANAGEMENT PRACTICES ON ENVIRONMENTAL PERFORMANCE AND COMPETITIVE ADVANTAGE: A CASE STUDY OF THE CEMENT INDUSTRY
}

\author{
Ehsan KHAKSAR ${ }^{\mathrm{a}}$, Tayyebeh ABBASNEJAD ${ }^{\mathrm{a}}$, Ahmad ESMAEILI ${ }^{\mathrm{b}}$, \\ Jolanta TAMOŠAITIENÉc \\ ${ }^{a}$ Department of Management, Faculty of Literature and Human Sciences, \\ Hormozgan University, Bandar Abbas, Iran \\ ${ }^{b}$ Department of Industrial Management, Faculty of Accounting and Management, \\ Allameh Tabataba'i University, 14348-63111 Tehran, Iran \\ ${ }^{c}$ Department of Construction Technology and Management, Research Laboratory \\ for Advanced Construction Technologies and Management, Civil Engineering Faculty, \\ Vilnius Gediminas Technical University, Sauletekio al. 11, LT 2040 Vilnius, Lithuania
}

Received 13 April 2015; accepted 15 June 2015

\begin{abstract}
Nowadays, sustainable development has been introduced and integrated into production and operation management field through the concept of the green supply chain. Green regulations and principles have gained the interest of managers and practitioners in selecting innovative practices for suppliers and organisations. Accordingly, the present study aims to evaluate the relationship between a green supplier, green innovation, environmental performance, and competitive advantage in the cement industry, which is an important industry for Iran. This study is descriptive in nature and conducted based on correlation and structural equation modelling. Managers and experts of cement companies in Fars Province are selected as samples for the study. A questionnaire and Smart-PLS software were used as research tools. The results of data analysis show that there is a positive and significant relationship between a green supplier, green innovations and environmental performance of an organisation, while there is a negative yet significant relationship between a green supplier, green innovations and environmental performance of an organisation. There is also a significant positive relationship between green innovation and environmental performance on one hand, and environmental performance and competitive advantage on the other.
\end{abstract}

Keywords: green supplier, environmental performance, green supply chain management, competitive advantage, green innovations.

JEL Classification: A12, C15, C80, E22. 


\section{Introduction}

The environmental issues in supply chain management are among the topics in the field of Production and Operations Management (Mathiyazhagan et al. 2013). Green supply chain management (GSCM) is a strategy for sustainable development in today's competitive markets, which aims to simultaneously achieve financial benefits and reduce environmental risks (Hajikhani et al. 2012). The advances in industrial production in terms of manufacturing techniques on one hand and increasing governmental regulations to protect the environment on the other, forced industrial organisations to further consider the concept of green supply chain management. According to several studies in the field, environmental issues in the supply chain are crucial, and widespread research has been conducted (Lampikoski 2012; Min, Kim 2012; Seman et al. 2012a), but the results are not conclusive in all contexts and industrial environments (Eltayeb et al. 2011). Accordingly, recent years show an increase in the development of sustainable supply chains throughout various industries (Seuring 2013) and organisations that seek to revive the industrial activity, achieve market growth or competitive advantage while focusing on environmental issues, such as depleting resources, environmental protection and reduction of pollution. Hence, there is an urgent need to develop innovative ways in economic activities (OECD 2012). Green innovation is one of the most effective factors in production and service delivery consistent with environmental issues. Anderson points out that research contributions on green innovation in the early stages of green supply chain development must be revisited and developed based on the contextual needs (Schiederig et al. 2012). If the origin of the innovation and creativity is traced back to the phase of a product or service development, one can claim the environmental friendliness of the process. Green innovation is based on studies of innovations in the processes and product innovation systems (Schiederig et al. 2011; Conding et al. 2012). Several studies were conducted between the years 2006 and 2008 by Chen, claiming that green innovation can be viewed in three different dimensions: green innovations in a product or in a process or green innovation as itself. He has introduced the concept of green innovation management, to the research area (Chiou et al. 2011). Furthermore, an interesting aspect of the green supply chain management is the compliance with environmental requirements of suppliers, in the case of which, the improper management would result in an increase in the costs for organisations (Simpson, Power 2005). Suppliers are in an emergent need to comply with the green requirements of the clients and the environmental standards within countries (Chiou et al. 2011). It should be noted that green innovation in supply chains and the environmental performance of companies has always been out of sight of researchers (Chiou et al. 2011; Schiederig et al. 2011). In this research, the authors have tried to answer the following question: Whether directly or indirectly, is there a significant relationship between green suppliers, green innovation, environmental performance and competitive advantage of the companies? The basis of the study is the adaptation using the model developed by Chiou et al. (2011) with a slight modification to contextualize the industrial needs. The selection of the industry can be judged based on the environmental impact and widespread locations of the cement companies in Iran, which 
has always been a critical issue for the society as the main stakeholders at risk. To do this, seven cement companies located in Fars Province were selected.

The structure of the research can be summarised as follows. In Section 1, the literature review is presented to outline the prior researches on green supply chain elements. Section 2 discusses the conceptual model of the study and Section 3 puts forward the case study of the research in the cement industry to validate the proposed theoretical model. The analysis of the data and hypotheses tests are discussed in Section 4 and the second section discusses the evaluation of the structural model of the research. Finally, the implications of the study and the discussion of the results are presented in the first part of the last section, and the managerial implications of the study for better understanding of the study in practice are presented in the last section.

\section{Survey of green supply chain management}

With increasing concerns about environmental pollution in the wake of industrialization in different countries and exploitation of natural resources, a common idea emerged among researchers regarding environmental issues in the supply chain (Shukla et al. 2011). The concept of green supply chain management was born in 1990 (Ghobakhloo et al. 2013; Shukla et al. 2011; Seman et al. 2012a). Today, sustainable development, or the social and environmental issues in the supply chain have become one of the main concerns of the researchers (Brandenburg et al. 2014). The review of the studies reveals that the first effort in the implementation of the GSCM occurred in 1994, and began with the green purchase concept. However later, due to the increasing importance of environmental issues, the necessity became apparent to implement green policies and standards at all stages of the supply chain (Hajikhani et al. 2012). Green Supply Chain can be defined as the concepts of mainstreaming environmental considerations in product design, selection and sourcing of raw materials, production, final product delivery to the customer and the management of after-sale effects in the supply chain (Seman et al. 2012b; Kildiene et al. 2014). The definitions being provided in the mainstream studies of the green supply chain must be used in conjunction with concepts such as eco-design (Eltayeb, Zailani 2009; Eltayeb et al. 2011; Sarkis et al. 2011), reverse logistics (Hajikhani et al. 2012; Eltayeb et al. 2011), green purchase (Hajikhani et al. 2012), green provision, environmentally friendly products and services (Large, Thomsen 2011; Hajikhani et al. 2012; Chiou et al. 2011; Gang 2015; Liou et al. 2015), and green innovation (Hottenrott et al. 2012; Machiba 2012; Schiederig et al. 2012; Chiou et al. 2011; Dutz, Sharma 2012; Lampikoski 2012), supply chain management practices on sustainability (Hashemkhani Zolfani et al. 2012; Alimardani et al. 2013; Meng 2013; Govindan et al. 2014; Martínez-Jurado, Moyano-Fuentes 2014), global supply chain network (Hasani et al. 2015; Boukherroub et al. 2015).

In addition, apparent developments are introduced to the green supply chain management model, including competitive advantage in micro-, messo-, macro-environments, including client requirements, achieved client success and satisfaction. The green supply chain management model is presented in Figure 1. 


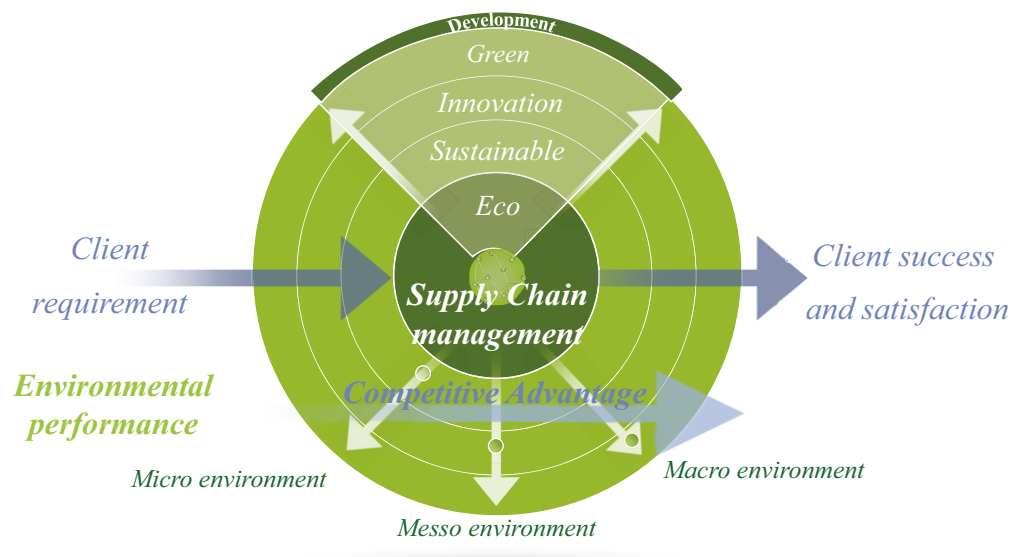

Fig. 1. Green supply chain management model

\subsection{Green supplier}

In a research, Hamner (2006) concluded that the collaboration to innovate in the supply chain is triggered by the supplier's and client's experience level, hence, companies can assist both sides to successfully implement the environmental management systems in the supply chain to improve suppliers' performance. Consistent with the prior claims, it can be stated that today's long-term competitive advantage depends on a close relationship with suppliers. To prevent damage to the supply chain routs, organisations must ensure that their suppliers act in accordance with predetermined social and environmental criteria in order to prevent abuse in supply processes (Reuter et al. 2010). Organisations seeking to change and enhance their competitive advantage must consider closer ties with suppliers and have the knowledge and skills necessary to improve the relationship with their suppliers (Chiou et al. 2011). Min and Kim (2012) identified the environmental factors influencing the decision on the selection of suppliers and investigated the impact of environmental factors being considered in purchase decisions. They emphasized the identified factors and suggested periodic assessment of the suppliers in the supply chain. Also, Large and Thomsen (2011) conducted a study in Germany and introduced five factors in the performance evaluation of green supply chain and assessment of green suppliers in the supply chain. The impact of obligations resulting from the innovation was investigated by Min and Kim (2012). They concluded that the stress put on the suppliers to develop green products resulted in a competitive advantage through cost reduction and better environmental performance for the supply chain. According to the researchers, supplier's commitment to innovation is one of the most important factors in the successful implementation of green supply chain management. Also, a supplier's commitment to green procurement will directly affect their commitment to provide the necessary materials and environmental needs into consideration. In a survey, which was conducted by Chiou et al. (2011), the relationship between green success and green innovation was confirmed. In another study, the direct impact of 
green innovations by suppliers and environmental performance of a company was also confirmed (Large, Thomsen 2011). In a recent study, Rostamzadeh et al. (2015) demonstrated a laptop manufacturer in Asia, which aims to assess green supply chain management (GSCM) indicators for its practitioners and suppliers. Through a thorough literature review, they confirmed the importance of green innovation in terms of eco-design throughout the entire supply chain.

\subsection{Green innovation}

The importance of green innovation in all fields of science originates from the fact that environmental concerns are on the rise all over the world. Various concepts, terminology and definitions provided for innovation, with a focus on its positive effect on the reduction of environmental pollution can be seen in the background research of the field (Iraldo et al. 2009). One of the earliest definitions of green innovation to be presented here can be phrased, as "the creation of new products and processes that has an added value for the customer and the dealer, but its main purpose is to reduce negative environmental impacts". Schiederig et al. (2012) also defined green innovation as "the creation or use of products (goods and services), processes, marketing practices, new organisational structures and organisations - with or without intent - leading to environmental improvements compared to prior trends". Practically, many organisations try to recover in the market and stay competitive. This cannot be achieved without consideration of global environmental challenges, such as climate changes and scarcity of natural resources, urging organisations to try and find new ways of doing business with the help of innovative activities. Last but not least, the continuous development and dissemination of green innovation, as well as environmental, economic and social benefits, are among the justifications behind the use of green innovations as a managerial tool. Now, it is rather apparent that the green innovation is one of the major factors in gaining success in the form of economic and social development at a national level and gain a competitive advantage and business success for companies (Machiba 2012). Also, according to Chen (2008), green innovation has a positive impact on competitive results. During literature review, the researchers have come across some studies regarding the trend analysis of evaluation and development of green innovations in varying dimensions (Schiederig et al. 2011; Conding et al. 2012; Lin et al. 2013), which have been used to develop the research model presented in this study.

\subsection{Environmental performance and competitive advantage}

Eltayeb et al. (2011) states that green supply chain management (GSCM), mostly due to its direct environmental, economic and operational results, is now one of the central issues discussed in the field of production and operations management. In a survey conducted by Porter and Van der Lind (1996), it was determined that in response to the company's competitive business environment and legal pressures, they must increase productivity and efficient use of resources, aimed at the improvement of the environmental performance of organisations (Hajikhani et al. 2012). Chiou et al. (2011) tried to provide an environmental 
performance index taking into account the environmental performance of suppliers. Regarding the relationship between environmental performance and competitive advantage, prior studies revealed an independent relationship and most of them consider the competitive advantage as a side consequence of GSCM. It can be stated that the direct relationship between environmental performance and competitive advantage has been understudied compared to other dimensions, which, in this case, can motivate organisations to implement GSCM as their strategy to gain competitive advantage.

Between the years 1994 and 2014, many studies examined the management of green supply chain focusing on the supplier selection processes and green innovation as a general concept (Zhu et al. 2008; Wu et al. 2011), but little attention has been paid to the environmental performance followed by green practices, which this study aims to reconsider and fill the research gap, both theoretically and practically.

\section{Developed theoretical model}

The main purpose of the study is based on different elements. What comes next, gives an account of previous studies in the GSCM context, expanding on different elements of the study. Various studies have been reviewed, among which the following are the most relevant. Carter et al. (2000), in a study on green procurement and its relationship with the company's performance, concluded that green procurement and cost of goods sold increase the net income of the parties. In search of green supply chain performance indicators in the electronics industry, a conclusion was made that the measures of green supply chain management and financial and functional outcomes are all parts of a whole system and there is a positive relationship between financial and operational implications of GSCM. Some of the elements analysed in this study were environmental laws, foreign shareholders of the company, the GSCM as a methodology of management, environmental performance and financial performance (Chien, Shih 2007). Iraldo et al. (2009) stated that although a good environmental design has a considerable impact on corporate environmental performance, but this effect on competitive factors, including market performance, productivity, resources and intangible assets is not considerable. Conding et al. (2012) conducted a study in 2012 and provided a model based on the green initiatives and green innovation in the automobile industry. They included innovation in products and processes as green innovation elements and the elements of green initiatives were listed as management of inbound processes, the integration technology, logistics management, customer and supplier. In search of the relationship between supply chain management and innovative green practices, Seman et al. (2012a) concluded that green supply chain management practices could create a capacity for green innovation in the organisation. They adopted elements, including the main process of innovation, management and product innovation as a component of green innovation and elements, including collaboration with customers, internal and environmental management, and reverse logistics as the components of supply chain management. Yang et al. (2013) conducted a research on Taiwanese container shipping companies, investigating the relationship between the internal and external actions with green performance and competitiveness. The structural equation modelling was used in 
this study. The results indicate that the inner and outer actions have a positive impact on green performance, which can positively affect competitive advantage of a given company. Internal measures, such as green marketing, green transportation practices, and green policies were analysed. Also, for external green practices, these measures include: collaboration with clients; green cooperation and collaboration with supply chain partners. The reduction in pollution rate and the reduction in costs were revealed as increased productivity, increase profit and improvement of service quality. The use of structural equation modelling for modelling of various elements increased due to its validity and power in a research method. For example, in another study, Zhu et al. (2013) used structural equation modelling to investigate the impact of institutional measures (legal, normative, competitive), internal measures (green design, green home environmental management), external measures (client work, return on investment, buying green) on the implications of green supply chain management (environmental, operational and economic). The results show that the institutional measures can stimulate internal and external measures. This study also found that green measures are not directly associated with economic performance, but an indirect improvement can be traced in the corporate performance. In the green supply chain management, few studies have been conducted in the country. The contradictions and unclear relation of the elements regarding green innovation, performance and competitive advantage can be justified by a comprehensive study, which is an intention of the authors of this study. The next section puts forward the main concepts and hypotheses of the study.

Based on the theoretical and empirical literature review, a conceptual model was developed adapting a model presented by Chiou et al. (2011). The research model is presented with a slight modification to meet the research gap and the industrial context. Figure 2 presents the model and the hypotheses of the research.

Based on the main question forwarded by researchers, the following hypotheses are proposed:

$\mathbf{H}_{\mathbf{1}}$ : Green innovation has significant relationships with suppliers.

$\mathbf{H}_{2}$ : Green suppliers are significantly associated with the environmental performance of organisations.

$\mathbf{H}_{3}$ : Green suppliers are significantly associated with the competitive advantage of the organisation.

$\mathbf{H}_{\mathbf{4}}$ : Green innovation is significantly associated with the environmental performance of organisations.

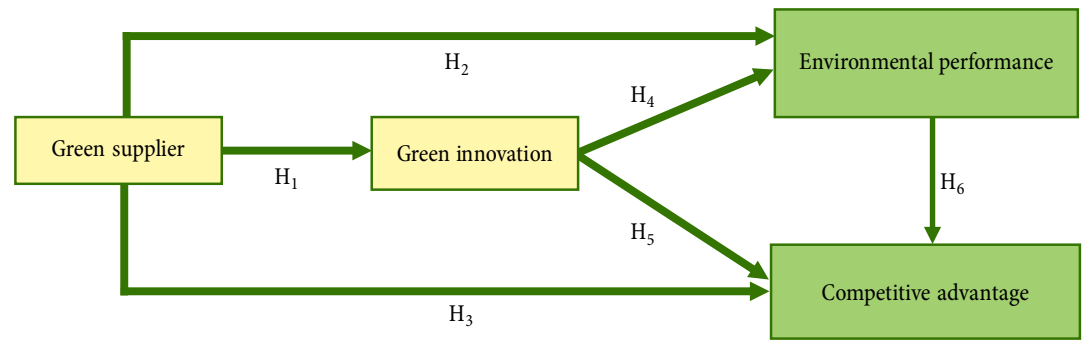

Fig. 2. Developed conceptual model (adapted from Chiou et al. 2011) 
$\mathbf{H}_{\mathbf{5}}$ : Green innovation is significantly associated with the competitive advantage for the organisation.

$\mathbf{H}_{\mathbf{6}}$ : There is a significant relationship between environmental performances of organisations and the competitive advantage of the organisation.

\section{A case study: the cement industry}

This research in terms of purpose and its method can be considered as a cross-correlation analysis based on structural equations. The population of the study consists of all the seven companies in the cement industry in Fars Province in Iran. In each company, the sample consisted of the CEO, the director, the production manager, the HSE manager, the maintenance manager, and S\&M (sales and marketing manager). Each factory has at least 3 direction experts (including senior managers in production lines and supply chain managers), 35 managers and 105 experts familiar with the research concepts. Therefore, using a two-stage cluster sampling and Morgan sampling tables, the sample size of 103 was calculated for this study. Thirty-six out of 92 managers and a total of 103 senior and middle managers, and experts were selected to be interviewed as the basic sample to increase the return rate of the questionnaires. To collect the data, the questionnaire was distributed. To analyse the research hypotheses, the path analysis was used. A generalization of the usual regression is regarded to be capable of identifying the direct effects and indirect associations of the elements. Smart-PLS Version II was used to assess the hypotheses. The application of structural equation modelling is based on the partial least square theorem. In addition, the rationale behind the selection of the software can be stated in the form of varying characteristics. Linearly independent variables and a small sample size, which is consistent but not normal, are among the justifications. More appraisal of the software can be found in next Sections.

\section{Processes of the analysis and results}

Analysis of structural equation modelling (evaluation of the relationship between manifested and latent variables) and the structural model assessment (assessment of the relationship between latent variables) is made. The results of the analysis are presented in the following sections.

\subsection{Assessment models and measured reflection}

A research questionnaire was designed using theoretical literature in the field. The questionnaire items were based on the elements extracted from Wu et al. (2011), Zhu et al. (2008) and Chiou et al. (2011), and then modified to meet the research gap and the industrial context. To ensure the content validity of data collection tools, several academic experts, managers and experts in the industry were asked to check the questionnaire. Also, prior to an examination of the hypotheses, we examined the validity and reliability of the 
instrument. Factor analysis of the reflection method assumes that the visible variable as one-dimensional. The single block Cronbach's alpha is greater than 0.7 , which shows the reliability of the questionnaire. Convergent validity and reliability of diagnostic assessment models were based on reflectance measurements. Fornell and Larcker (1981) offered the convergent validity as a measure of the average variance. The assessment are reflected in the models presented in following sections of this paper. Fornell-Larcker criteria were used for the diagnostic validity. The biggest factor loadings for each variable appears to be related to the latent variable and the factor loadings on other latent variables should be smaller than this value. The diagnostic validity and values of the average variance extracted (AVE) for all variables were greater than the desired level of 0.5 . The structural and the Cronbach's alpha reliability coefficients for all variables in the model were at optimal levels ( 0.7 or above), which can be accepted on the grounds of theory. Table 1 presents the results of validity and reliability test for each variable in the model.

Latent variables in Table 2 using descriptive statistics, presents the means and standard deviations of each variable.

Table 1. Results of measuring the reflection models

\begin{tabular}{lccc}
\hline \multicolumn{1}{c}{ Variable } & $\begin{array}{c}\text { Credit convergence } \\
\text { (AVE) }\end{array}$ & $\begin{array}{c}\text { Cronbach's alpha } \\
\text { (CA) }\end{array}$ & $\begin{array}{c}\text { Structural reliability } \\
\text { coefficient (CR) }\end{array}$ \\
\hline Green supplier & 0.6433 & 0.8847 & 0.9132 \\
\hline Green innovation & 0.6671 & 0.7683 & 0.8260 \\
\hline Environmental performance & 0.5836 & 0.7913 & 0.7528 \\
\hline Competitive advantage & 0.8137 & 0.9244 & 0.9461 \\
\hline
\end{tabular}

Table 2. Descriptive statistics of latent variables

\begin{tabular}{lcc}
\hline \multicolumn{1}{c}{ Variable } & Average & Standard Deviation \\
\hline Green supplier & 2.333 & 0.38 \\
\hline Green innovation & 3.17 & 0.57 \\
\hline Environmental performance & 3.71 & 0.74 \\
\hline Competitive advantage & 3.29 & 0.45 \\
\hline
\end{tabular}

\subsection{Evaluation of the structural model}

Figure 3 shows the conceptual model after analysis. The numbers written on the lines of the beta coefficients are extracted from the regression equation coefficients of the variables or in other terms from the path analysis. The number in each circle indicates the value of $\mathrm{R}^{2}$. The coefficient determining $\mathrm{R}^{2}$ for the correlation between the amounts of variance is explained by the covariance of the measurement and is considered as a latent variable. The coefficient of $\mathrm{R}^{2}$ determination is to predict the dependent variable by variables to be assessed independently. Obviously, the value of this index is calculated only for the dependent variables. 


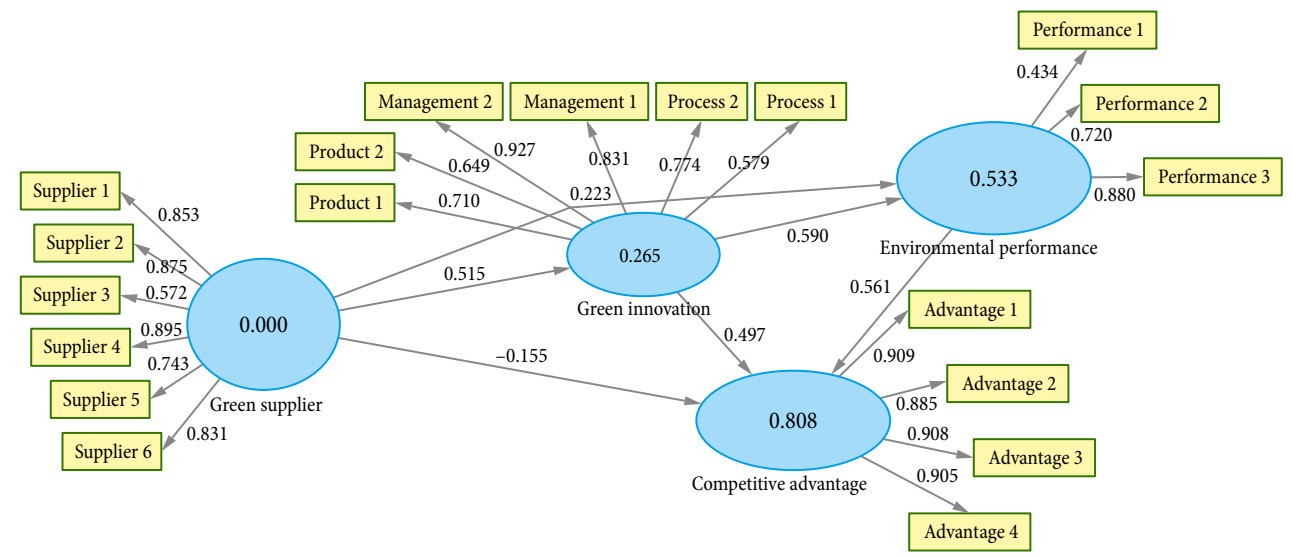

Fig. 3. Determination of the coefficient $\mathrm{R}^{2}$ and path coefficients between the independent and dependent variables

As shown in Figure 3, the independent variables can be predicted by being more than half of the variance in the dependent variable (the variable) and this demonstrates the ability to predict the model. Predictability using a nonparametric test glyceride Stone is also assessed. $\mathrm{Q}^{2}$ is used to assess that to what extent the analysis is correct. If the $\mathrm{Q}^{2}$ values are positive and large enough, the predictability of the model is verified. $\mathrm{Q}^{2}$ value for each latent variable is shown in Table 3.

Table 3. $\mathrm{Q}^{2}$ values for the latent variables

\begin{tabular}{lcc}
\hline \multicolumn{1}{c}{ Variable } & CV Com & CV Red \\
\hline Green supplier & 0.506 & 0.506 \\
\hline Green innovation & 0.421 & 0.123 \\
\hline Environmental performance & 0.093 & 0.259 \\
\hline Competitive advantage & 0.666 & 0.590 \\
\hline
\end{tabular}

To assess the significance of the path coefficients, t-value needs to be calculated. Figure 4 represents the calculated $t$-value for the dependent and independent variables. The structural equation analysis of the t-model is to measure the impact of solidarity and independent variables on the dependent variable and can be used as a criterion to test the hypotheses. Theoretically, if the value obtained for each hypothesis is greater than the absolute value of 1.96, the hypothesis is confirmed, and the smaller values will result in the rejection of hypotheses. As shown in Figure 4 all the values calculated are greater than the assumption (1.96) and the research hypotheses are approved as being related. In other words, the relationships between the variables, regardless of the quality of the relationships (positive or negative), are approved.

Some researchers believe that if the path coefficients are greater than 0.1, a certain amount of influence in the model can be verified (Hair et al. 2011). Also, the path coefficients should be at least 0.05 . As shown in Table 3, hypotheses at a significance level of 95\% are approved. 


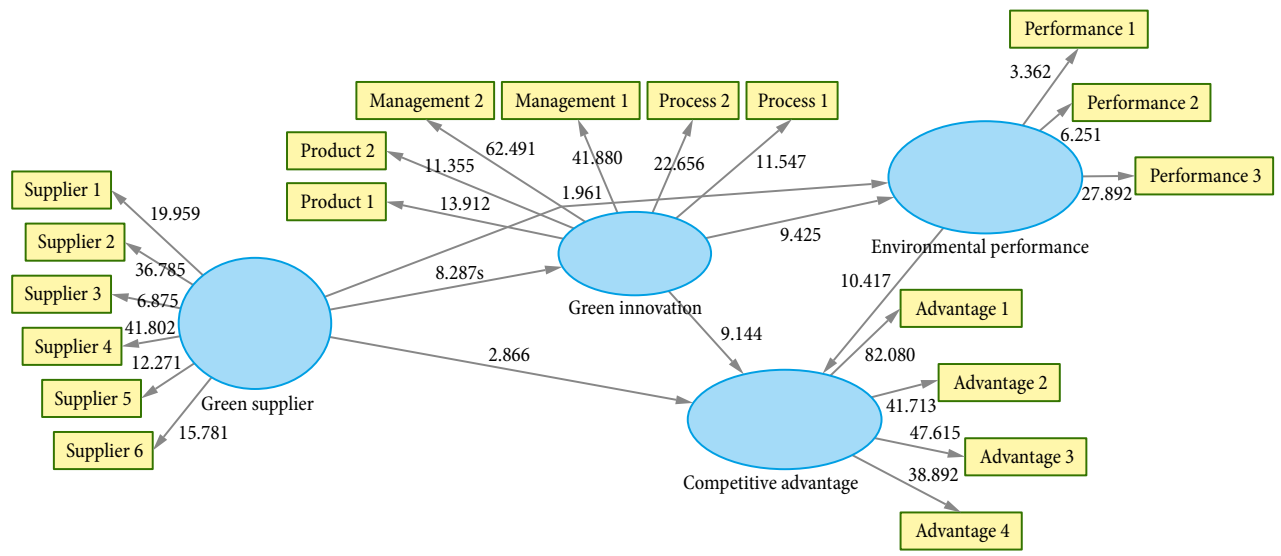

Fig. 4. T-statistic for the variables

Table 4. Final results of the study regarding hypotheses

\begin{tabular}{llcccc}
\hline No $\quad$ Hypotheses & $\begin{array}{c}\text { Path } \\
\text { Coefficient }\end{array}$ & $\begin{array}{c}\text { Mark } \\
\text { Algebraic } \\
\text { Equation }\end{array}$ & T Statistics & $\begin{array}{c}\text { Significance } \\
\text { Level }\end{array}$ & $\begin{array}{c}\text { Approved } \\
\text { or Rejected }\end{array}$ \\
\hline $\begin{array}{l}\text { Green innovation has a } \\
\text { significant relationships } \\
\text { with suppliers }\end{array}$ & 0.515 & + & 8.708 & 0.000 & Approved \\
\hline $\begin{array}{l}\text { Green suppliers are } \\
\text { significantly associated } \\
\text { with the environmental } \\
\text { performance } \\
\text { of organisations }\end{array}$ & 0.223 & + & 2.204 & 0.000 & Approved \\
\hline $\begin{array}{l}\text { Green suppliers are } \\
\text { significantly associated with } \\
\text { the competitive advantage } \\
\text { of the organisation }\end{array}$ & -0.155 & - & 2.762 & 0.000 & Approved \\
\hline $\begin{array}{l}\text { Green innovation is } \\
\text { significantly associated } \\
\text { with the environmental } \\
\text { performance of } \\
\text { organisations }\end{array}$ & 0.590 & + & 10.286 & 0.000 & Approved \\
\hline $\begin{array}{l}\text { Green innovation is } \\
\text { significantly associated with } \\
\text { the competitive advantage } \\
\text { for the organisation }\end{array}$ & 0.497 & & & & \\
\hline $\begin{array}{l}\text { There is a significant } \\
\text { relationship between } \\
\text { environmental } \\
\text { performances of } \\
\text { organisations and the } \\
\text { competitive advantage } \\
\text { of the organisation. }\end{array}$ & 0.561 & + & & & \\
\hline
\end{tabular}


The approval of the hypotheses paves the way to the analysis of the type of relationship between variables. Table 4 displays the analysis results, which are based on the path coefficients. All the relationships stated in the hypotheses are positive except for the relationship between the green supplier and the competitive advantage. According to the directions index, we can see the negative relationship between green suppliers and the competitive advantage.

\section{Discussion and conclusions}

Recently, there is a growing focus on the environmental issues as well as the trend among countries and organisations to search for sustainability. The growing popularity of the issues is clearly demonstrated by the focus of the scientific research in the area. Several studies have addressed these issues. Green supply chain management practices - one of the main environmental factors that are of great importance. Numerous studies have been conducted in this area, each considering various factors in the theory and practice. Although, the main focus remained on the green supply chain practices and the assessment of the indicators as well as the outcomes of those practices. However, the relationship between some elements has not been clearly investigated. In this study, attempts have been made to fill the gap in the literature trying to analyse the relationship between four basic elements including: a green supplier, green innovation, environmental performance and competitiveness. The results demonstrated the relationship between the four variables. The results are in accordance with the results obtained by Lin et al. (2013) and Conding et al. (2012). The approval of the relationship can be seen as one phase, which must be completed by the analysis of the quality of the relationship being positive or negative. The $\mathrm{R}^{2}$ coefficient of determination and the path coefficients between the independent and dependent variables underlying the model confirmed the initial assumptions. The coefficient indicates the direction as one-sided or two-sided. As the Figure 4 suggests, all numbers (path coefficients) of calculated path coefficients are positive except for the relationship between green suppliers and the competitive advantage. These results also confirm the results obtained from Chiou et al. (2011), Seman et al. (2012a) and Conding et al. (2012). The negative path coefficient between the green suppliers and the competitive advantage indicates an issue that is not compatible with earlier research contributionss. There was a negative correlation between these two variables that can be traced back to the costs around the green supply. Since attention of the suppliers to environmental issues is a costly activity, an important task for the client companies would be the education of suppliers to improve processes related to the green supply. Also, the allocation of special funds can enhance the attention of the suppliers.

It can stated that in organisations that operate in competetive markets, the focus of the managers has been on the profitability and the applicability of the organisational strategies and activities. Given that the cost of the activities (green innovation and selection of green suppliers) in terms of practicality equals to the profits gained from the activities, the analysis into the effectiveness of the practices is of great importance. The analysis made in this paper can assist managers of the cement industry with gaining a perspective on the costs and feasibility of these activities prior to taking action and adopt the most feasible 
and profitable activities in terms of being environmentally friendly and economically practical. The collaboration with suppliers can directly affect green innovation practices, as well as environmental performance. Also, green innovation has a positive and direct impact on environmental performance and gaining competitive advantage. CEOs and the main stakeholders of these companies can be assured that not only these green practices have no a negative impact on overall performance, but also they are cost justified and have a positive impact on the performance and competitive advantage of companies. One must not neglect the negative correlation between a green supplier and the competitive advantage of the company. In this respect, careful examination of the costs and direct and indirect impacts of this decision, is considerably important. Previous literature results reveal this factor as being one of the key elements in green supply chain management practices (Rao 2002). Simply ignoring this factor due to its negative correlation is not a practical decision. However, taking some action to minimize the negative impacts and maximize the positive impact can be a rational solution for managers (Rostamzadeh et al. 2015).

No research is without limitation. Due to the limitations of the data collected in this study, the effect of many variables was not considered. The future research efforts can take into account the buyer-related variables such as the size of the organisation, practices in the industry, market pressures and cost pressures on the green supply chain members. The decision-making theories, can also be of great use for the companies seeking to improve the priority of the practices in the market to gain the best possible outcome, economically, environmentally and socially.

\section{References}

Alimardani, M.; Hashemkhani Zolfani, S.; Aghdaie, M. H.; Tamošaitienė, J. 2013. A novel hybrid SWARA and VIKOR methodology for supplier selection in an agile environment, Technological and Economic Development of Economy 19(3): 533-548. http://dx.doi.org/10.3846/20294913.2013.814606

Boukherroub, T.; Ruiz, A.; Guinet, A.; Fondrevelle, J. 2015. An integrated approach for sustainable supply chain planning, Computers \& Operations Research 54: 180-194. http://dx.doi.org/10.1016/j.cor.2014.09.002

Brandenburg, M.; Govindan, K.; Sarkis, J.; Seuring, S. 2014. Quantitative models for sustainable supply chain management: developments and directions, European Journal of Operational Research 233(2): 299-312. http://dx.doi.org/10.1016/j.ejor.2013.09.032

Carter, C.; Kale, R.; Grimm, C. M. 2000. Environmental purchasing and firm performance: an empirical investigation, Transportation Research Part E: Logistics and Transportation Review 36(3): 219-228. http://dx.doi.org/10.1016/S1366-5545(99)00034-4

Chen, Y.-S. 2008. The driver of green innovation and green image-green core competence, Journal of Business Ethics 81(3): 531-543. http://dx.doi.org/10.1007/s10551-007-9522-1

Chien, M.-K.; Shih, L.-H. 2007. An empirical study of the implementation of green supply chain management practices in the electrical and electronic industry and theirrelation to organizational performances, International Journal of Environmental Science and Technology 4(3): 383-394.

Chiou, T.-Y.; Chan, H. K.; Lettice, F.; Chung, S. H. 2011. The influence of greening the suppliers and green innovation on environmental performance and competitive advantage in Taiwan, Transportation Research Part E: Logistics and Transportation Review 47(6): 822-836.

http://dx.doi.org/10.1016/j.tre.2011.05.016 
Conding, J.; Zubir, A. F. M.; Hashim, S. A.; Lanang, N. A. S. 2012. A proposed of green practices and green innovation model in Malaysian automotive industry, Environmental Management and Sustainable Development 1(2): 90-100. http://dx.doi.org/10.5296/emsd.v1i2.2183

Dutz, M.; Sharma, S. 2012. Green growth, technology and innovation, Policy Research Working Paper, 1-45. http://dx.doi.org/10.1596/1813-9450-5932

Eltayeb, T. K.; Zailani, S.; Ramayah, T. 2011. Green supply chain initiatives among certified companies in Malaysia and environmental sustainability: Investigating the outcomes, Resources, conservation and recycling 55(5): 495-506.

Eltayeb, T.; Zailani, S. 2009. Going green through green supply chain initiatives towards environmental sustainability, Operations and Supply Chain Management 2(2): 93-110. http://dx.doi.org/10.1016/j.resconrec.2010.09.003

Fornell, C.; Larcker, D. F. 1981. Evaluating structural equation models with unobservable variables and measurement error, Journal of Marketing Research 18(1): 39-50. http://dx.doi.org/10.2307/3151312

Gang, X. 2015. Modeling decision processes of a green supply chain with regulation on energy saving level, Computers \& Operations Research (54): 266-273.

Ghobakhloo, M.; Tang, S. H.; Zulkifli, N.; Ariffin, M. K. A. 2013. An integrated framework of green supply chain management implementation, International Journal of Innovation, Management and Technology 8(1): 86-89.

Govindan, K.; Azevedo, S.; Carvalho, H.; Cruz-Machado, V. 2014. Impact of supply chain management practices on sustainability, Journal of Cleaner Production 85: 212-225.

http://dx.doi.org/10.1016/j.jclepro.2014.05.068

Hashemkhani Zolfani, S.; Chen, I.-S.; Rezaeiniya, N.; Tamošaitienè, J. 2012. A hybrid MCDM model encompassing AHP and COPRAS-G methods for selecting company supplier in Iran, Technological and Economic Development of Economy 18(3): 529-543.

http://dx.doi.org/10.3846/20294913.2012.709472

Hasani, A.; Zegordi, S. H.; Nikbakhsh, E. 2015. Robust closed-loop global supply chain network design under uncertainty: the case of the medical device industry, International Journal of Production Research 53(5): 1596-1624. http://dx.doi.org/10.1080/00207543.2014.965349

Hajikhani, M.; Wahat, N. W.; Idris, K. B. 2012. Considering on green supply chain management drivers, as a strategic organizational development approach, Malaysian perspective, Australian Journal of Basic and Applied Sciences 6(8): 146-165.

Hottenrott, H.; Rexhauser, S.; Veugelers, R. 2012. Green innovations and organizational change: making better use of environmental technology, ZEW-Centre for European Economic Research Discussion Paper 43(12): 1-26.

Hamner, B. 2006. Effects of green purchasing strategies on supplier behaviour, in J. Sarkis. (Ed.). Greening the supply chain. London: Springer Publishing, 25-37. http://dx.doi.org/10.1007/1-84628-299-3_2

Hair, J. F; Ringle, C. M.; Sarstedt, M. 2011. PLS-SEM: indeed a silver bullet, Journal of Marketing Theory and Practice 19(2): 139-152. http://dx.doi.org/10.2753/MTP1069-6679190202

Iraldo, F.; Testa, F.; Frey, M. 2009. Is an environmental management system able to influence environmental and competitive performance? The case of the eco-management and audit scheme (EMAS) in the European union, Journal of Cleaner Production 17(16): 1444-1452.

http://dx.doi.org/10.1016/j.jclepro.2009.05.013

Kildienė, S.; Zavadskas, E. K.; Tamošaitienè, J. 2014. Complex assessment model for advanced technology deployment, Journal of Civil Engineering and Management 20(2): 280-290. http://dx.doi.org/10.3846/13923730.2014.904813

Lampikoski, T. 2012. Green, innovative, and profitable: a case study of managerial capabilities at Interface Inc, The Technology Innovation Management Review 35: 4-12. 
Large, R. O.; Thomsen, C. G. 2011. Drivers of green supply management performance: evidence from Germany, Journal of Purchasing and Supply Management 17(3): 176-184. http://dx.doi.org/10.1016/j.pursup.2011.04.006

Lin, R.-J.; Tan, K.-H.; Geng, Y. 2013. Market demand, green product innovation, and firm performance: evidence from Vietnam motorcycle industry, Journal of Cleaner Production 40: 101-107. http://dx.doi.org/10.1016/j.jclepro.2012.01.001

Liou, J. J. H.; Tamošaitiene, J.; Zavadskas, E. K.; Tzeng, G.-H. 2015. New hybrid COPRAS-G MADM Model for improving and selecting suppliers in green supply chain management, International Foundation for Production Research (53): 1-21.

Machiba, T. 2012. The future of eco-innovation: the role of business models in green transformation. OECD background paper, in Proceedings of the OECD/European Commission/Nordic Innovation Joint Workshop, 19-20 January 2012, Copenhagen, Denmark.

Martínez-Jurado, P. J.; Moyano-Fuentes, J. 2014. Lean management, supply chain management and sustainability: a literature review, Journal of Cleaner Production 85(15): 134-150. http://dx.doi.org/10.1016/j.jclepro.2013.09.042

Mathiyazhagan, K.; Govindan, K.; Noorul, H. A.; Geng, Y. 2013. An ISM approach for the barrier analysis in implementing green supply chain management, Journal of Cleaner Production 47: 283-297. http://dx.doi.org/10.1016/j.jclepro.2012.10.042

Meng, X. 2013. Change In UK construction: moving toward supply chain collaboration, Journal of Civil Engineering and Management 19(3): 422-432. http://dx.doi.org/10.3846/13923730.2012.760479

Min, H.; Kim, I. 2012. Green supply chain research: past, present, and future, Logistics Research 4(1-2): 39-47. http://dx.doi.org/10.1007/s12159-012-0071-3

OECD. 2012. The future of eco-innovation: the role of business models in green transformation, in OECD/European Commission/Nordic Innovation Joint Workshop, 19-20 January 2012, Danish Business Authority, Copenhagen, Denmark. 27 p.

Porter, M. E.; Van Der Linde, C. 1996. Ecology increases business competitiveness, Harvard Business Review 2: 12-13.

Rao, P. 2002. Greening the supply chain: a new initiative in South East Asia, International Journal of Operations \& Production Management 22(6): 632-655. http://dx.doi.org/10.1108/01443570210427668

Reuter, C.; Foerstl, K.; Hartmann, E.; Blome, C. 2010. Sustainable global supplier management: The role of dynamic capabilities in achieving competitive advantage, Journal of Supply Chain Management 46(2): 45-63. http://dx.doi.org/10.1111/j.1745-493X.2010.03189.x

Rostamzadeh, R.; Govindan, K.; Esmaeili, A.; Sabaghi, M. 2015. Application of fuzzy VIKOR for evaluation of green supply chain management practices, Ecological Indicators 49: 188-203. http://dx.doi.org/10.1016/j.ecolind.2014.09.045

Sarkis, J.; Zhu, Q.; Lai, K.-H. 2011. An organizational theoretic review of green supply chain management literature, International Journal of Production Economics 130(1): 1-15. http://dx.doi.org/10.1016/j.ijpe.2010.11.010

Schiederig, T.; Tietze, F.; Herstatt, C. 2011. What is green Innovation? A quantitative literature review, Working Papers/Technologie-und Innovationsmanagement, Technische Universität HamburgHarburg.

Schiederig, T.; Tietze, F.; Herstatt, C. 2012. Green innovationin technology and innovation management-an exploratory literature review, $R \& D$ Management 42(2): 180-192. http://dx.doi.org/10.1111/j.1467-9310.2011.00672.x

Seman, N.; Zakuan, N.; Jusoh, A.; Arif, M. 2012a. Green supply chain management: a review and research direction, International Journal of Managing Value And Supply Chain 3(1): 1-18. http://dx.doi.org/10.5121/ijmvsc.2012.3101

Seman, N.; Aslinda, A.; Zakuan, N.; Jusoh, A.; Arif, M. S. M.; Saman, M. Z. M. 2012b. The relationship of green supply chain management and green innovation concept, Procedia-Social and Behavioral Sciences 57: 453-457. http://dx.doi.org/10.1016/j.sbspro.2012.09.1211 
Seuring, S. 2013. A review of modeling approaches for sustainable supply chain management, Decision Support Systems 54(4): 1513-1520. http://dx.doi.org/10.1016/j.dss.2012.05.053

Shukla, R. K.; Garg, D.; Agarwal, A. 2011. Understanding of supply chain: a literature review, International Journal of Engineering Science and Technology 3(3): 2059-2072.

Simpson, D. F.; Power, D. J. 2005. Use the supply relationship to develop lean and green suppliers, Supply Chain Management: An International Journal 10(1): 60-68.

Wu, K.-J.; Tseng, M.-L.; Vy, T. 2011. Evaluation the drivers of green supply chain management practices in uncertainty, Procedia-Social and Behavioral Sciences 25: 384-397.

http://dx.doi.org/10.1016/j.sbspro.2012.02.049

Yang, S.; Lu, C.; Haider, J.; Marlow, P. 2013. The effect of green supply chain management on green performance and firm competitiveness in the context of container shipping in Taiwan, Transportation Research Part E: Logistics and Transportation Review 55: 55-73.

http://dx.doi.org/10.1016/j.tre.2013.03.005

Zhu, Q.; Sarkis, J.; Cordeiro, J. J.; Lai, K.-H. 2008. Firm-level correlates of emergent green supply chain management practices in the Chinese context, Omega 36: 577-591. http://dx.doi.org/10.1016/j.omega.2006.11.009

Zhu, Q.; Sarkis, J.; Lai, K. H. 2013. Institutional-based antecedents and performance outcomes of internal and external green supply chain management practices, Journal of Purchasing and Supply Management 19(2): 106-117. http://dx.doi.org/10.1016/j.pursup.2012.12.001

Ehsan KHAKSAR has M.A in Industrial Management. He is consulting consultant of industrial projects in a private company. He has performed several studies in the field of supply chain management. His efforts are published in four papers and one book. In addition to consultation, he teaches specialised software such as SPSS and AMOS. His areas of interest include supply chain management, technology management, techniques and marketing methods, MCDM techniques.

Tayebeh ABBASNEJAD. Assoc. prof. Dr Tayebeh Abbasnejad is manager of the Department of Industrial and Public Management at Hormozgan University, Bandar-Abbas, Iran. She published five scientific papers. Research interests: technology management, operations research, operations and production management, innovation management, supply chain management, decision-making theory, optimization, strategies, developing alternatives of sustainable development for business and management in industry.

Ahmad ESMAEILI is a PhD candidate in production \& operations management at Allameh Tabataba'i University. He has authored numerous papers on supply chain management and service quality. He works in a private management consulting company in Iran. His areas of interest include supply chain management, technology management, MCDM methods and service quality models.

Jolanta TAMOŠAITIENĖ. Assoc. prof. Dr Jolanta Tamošaitienè is a Vice-Dean of Civil Engineering Faculty and working in the Dept. of Construction Technology and Management at Vilnius Gediminas Technical University, Lithuania. Since 2013, she is a member of the Editorial Board of "The Journal of Engineering, Project, and Production Management"; since 2011, she is a member of the Editorial Board of the journal "Technological and Economic Development of Economy". Since 2009, she is a member of EURO Working Group OR in Sustainable Development and Civil Engineering, EWG-ORSDCE. She published 50 scientific papers. Research interests: many miscellaneous management areas (enterprise, construction project and etc.), risk assessment, construction project administration, building life-cycle, construction technology and organisation, decision-making and grey system theory, Decision Making (DM), statistics, optimization, strategies, game theory, intelligent support system, Sustainable Development: developing of alternative construction processes, economic and other aspects, sustainable development challenges for business and management in construction enterprises, environmental impact processes and etc. 